\title{
Global Value Chains, Trade and Technology: Evidence from European Countries
}

Author(s): Kore Marc. Guei

Source: Journal of International Logistics and Trade 2021; 19(2):83-94

Published by: Jungseok Research Institute of International Logistics and Trade, Inha University

DOI: https://doi.org/10.24006/jilt.2021.19.2.083

Journal of International Logistics and Trade is an official journal published by Jungseok Research Institute of International Logistics and Trade, Inha University, Korea. JILT welcomes manuscripts that advance the practice and science of logistics, trade, and other related fields.

Frequency: Quarterly (March, June, September, December)

Stable URL: https://www.ejilt.org

Jungseok Research Institute of International Logistics and Trade is a specialized academic research institute representing Inha University and Inha Foundation in Korea. The institute aims to become a representative institute in Northeast Asia in the research of logistics and trade.

Stable URL: https://jrieng.inha.ac.kr

(C) Copyright. Jungseok Research Institute of International Logistics and Trade.

This is an Open-Access article distributed under the terms of the Creative Commons Attribution NonCommercial License (http://creativecommons.org/licenses/by-nc/4.0/) which permits unrestricted noncommercial use, distribution, and reproduction in any medium, provided the original work is properly cited 



\section{Journal of International Logistics and Trade}

J. Int. Logist. Trade, 2021, Vol. 19, No. 2, 83-94

pISSN : 1738-2122 eISSN : 2508-7592

https://doi.org/10.24006/jilt.2021.19.2.083

https://www.ejilt.org

\section{ARTICLE}

\section{Global Value Chains, Trade and Technology: Evidence from European Countries}

Kore Marc. Guei*

DST/NRF/Newton Fund Trilateral Research Chair in Transformative Innovation, the Fourth Industrial Revolution and Sustainable Development, University of Johannesburg, South Africa

Received May 01, 2021
Revised June 16, 2021
Accepted June 18, 2021

*Corresponding author: Kore Marc. Guei
DST/NRF/Newton Fund Trilateral Research
Chair in Transformative Innovation, the
Fourth Industrial Revolution and
Sustainable Development, University of
Johannesburg, South Africa
Tel: +27633963451
E-mail: marcgueik@gmail.com

Received May 01, 2021

Revised June 16, 2021

Accepted June 18, 2021

*Corresponding author: Kore Marc. Guei Chair in Transformative Innovation, the Fourth Industrial Revolution and Johannesburg, South Africa

E-mail: marcgueik@gmail.com

\begin{abstract}
The paper investigates the effects of global value chains (GVCs) and technological innovation on exports. The paper builds a new dataset from two database, the EORA and the OECD stan database. Using a pooled OLS and a two-stage quantile regression technique on a sample of 8 OECD countries, the results suggest that the effects of GVCs participation are heterogeneous across countries. We find that at the aggregate level, GVCs and forward participation are negatively associated with exports growth. However, we only find evidence of a positive effect of backward participation on exports in the case of France and Germany. At the disaggregated level, we find that: (a) an increase in GVCs participation in low technology intensive sectors is positively associated with exports'growth; (b) an increase in GVCs participation in high technology intensive sector is negatively correlated with exports'growth. The findings stress the importance of GVCs as a driving channel for subdue economic growth in low technological sectors.
\end{abstract}

Keywords Global value chains, Exports, Innovation

\section{Introduction}

Global value chain $(\mathrm{GVC})$ has transformed the world trade system. The $21^{\text {st }}$ century is now characterized by the global value chains (GVCs) where the steps involved in the production process of a single good are spread internationally. There is a strong argument in the literature that participation in GVCs allows firms to increase their production level through different channels such as specialization and knowledge transfers from foreign enterprises (OECD 2013). Nevertheless, the empirical evidence on the effects of GVC participation on bilateral exports is incomplete.

A large body of literature has documented that GVC enables firms to have access to a larger market, higher quality of products and sophisticated inputs which in turn can trigger productivity and boost exports (Collier and Venables, 2007; Pahl and Timmer, 2019). Industrialisation is now considered to be as easy as ever since all countries can access global markets with a stable macroeconomic environment. For instance, Rodrik (2013) points out that countries that are behind in terms of productivity can reach the level of world productivity leader, irrespective of the countries' characteristics.

Early empirical literature on the link between productivity and exports has shown little evidence that exports growth is associated with rising productivity (Bernard and Jensen, 2004). Rodrik (2013) supports the hypothesis that countries that engage in GVCs may benefit from technological transfer and less so from employment in the labour market. Baldwin (2014) also supports this finding by arguing that although entry in the global market boost productivity and employment in the short run, there is no guarantee that industrialisation will be sustained if capacity building is not maintained.

Further, the technological advances that come with the production of GVC contribute to the substitution of unskilled labour for automation (Rodrik 2018). This is because the global market requires accuracy and strict adherence to international agreed standards. This development shows that while GVC participation may benefit highly productive firms, it occurs at the expense of employment opportunities.

Recent studies have examined the relationship between GVC participation and economic growth. The work of Constantinescu et al. (2019) that examines the role of vertical specialization on productivity in a panel of 40 countries concludes that GVC participation is an important driver of labour productivity.

Kummritz et al. (2017) find that trade integration causes a rise in the value added of an industry. This increase is amplified when the industry participates in upstream stages. Also, Lopez-Gonzalez (2016) shows that there is positive impact from the 
imports of intermediates on a country's employment, value added and services in ASEAN countries. It appears that there is a consensus in the literature that trade integration is essential for GDP growth, as countries tend to become what they export.

Yet, these research are based on data that departs from one another in terms of the sectors considered, the trade agreements between countries, and the level of development. We aim to fill the gap in this paper, by examining the potential impact of GVC participation on bilateral exports. Specifically, we investigate whether GVC participation at the macroeconomic level contribute to exports growth. Secondly, we study the effect of GVC participation at the sectoral level.

We answer these questions by taking into account a highly disaggregated data from selected European countries. Our measure of GVC participation is calculated as the sum of the share of a country's domestic value added (forward participation) which is considered an intermediate input in the value added of exports by the other country and the share of foreign valued added (which is referred to as backward participation).

Another novel contribution of the study is that we investigate the effects of GVCs at the sectoral level. Different levels of investment are allocated to technology intensive and non-technology intensive sectors, therefore we assess the role of GVCs in each sector in our sample. This strategy allows to control for specific industry characteristics. The results show that GVC participation of low technological industries (Basic metal, textile, rubber and plastic products) have contributed positively and significantly to bilateral exports. Whereas GVC participation of industries considered to be technology intensive (chemicals, electrical equipment, and telecommunication) are negatively associated with exports.

The paper adds to the growing literature on the nexus between globalisation and economic growth. Recent studies on the topic are worth to be mentioned, for instance Taglioni and Winkler (2016) document that identical industries, different governance strategies can explain the heterogeneous effect of GVC participation and local sourcing. Using a survey of multinational firms, they show that linkages to local suppliers are higher in Vietnam compared to African countries (Mozambique, Kenya, and Ghana). Kummritz et al. (2017) have focused on industrial upgrading and international trade. They examine which national strategies have important for a successful upgrade in GVCs by combining a set of advanced economies at the sectoral level.

Based on the core analysis of the methodology employed by these studies, we identity two school of thought within the literature of GVC: the internationalists who focus on a macro perspective framework and the industrialists who privilege a microeconomic framework that is geared towards cluster development. These classifications help to bring out the similarities and differences among each group.

The original contribution of the paper is to reconcile these two views by proposing an analytical framework that examines the role of GVC participation in the context of EU countries. The rest of the paper is organised as follows: Section 2 provides a discussion of the literature on GVCs. Section 3 presents the model and describes the data sources. Section 4 discusses the results. Section 5 concludes.

\section{Theoretical background}

The literature on GVCs has played an important role in explaining the capability-upgrading of global firms through the interaction of buyers on one side and sellers on the other along the value chain.

The global economic slowdown of many advanced industrial nations and the rapid rise of emerging countries has triggered the regionalisation of GVCs. The development of regional production network in emerging economies has redefined the world trade system. For instance, the East Asian Market has emerged with a strong supply base and complementarities which help spur growth in the region. Many electronic products are supplied from Japan and Korea because of the high investment in research and development (R\&D) and then assembled in China or in other low-income country such as Vietnam (WTO and IDE-JETRO 2011). Although upgrading outcome help advance the positions of firms that participate in GVCs, the gains obtained by contract manufacturing firms in low-income economy are low compared to component suppliers like Japan.

This division of labour is not a new phenomenon, more goods in different industries are produced and consumed locally or regionally rather than being exported to advanced economies. Countries in Sub-Saharan Africa are becoming more integrated with the proliferation of supermarkets across the region.

South African and Kenyan producers have found a new demand for their products in Asia and the Middle East (Barrientos and Visser 2012). This has led to the development of the South-South value chains.

This change in dynamics has clearly benefited emerging economies. This is because the share of advanced economies in total value added over the past two decades reduce by $18 \%$ while that of emerging countries increase by the same percentage (Timmer et al. 2014). 
In majority of the literature on GVCs, there is the premature belief that the upgrading-process would cause social gains and enhance the well-being of labour in the value chains. Some evidence on the other hand suggests that economic upgrading can actually worsens social conditions (Lee et al. 2011).

Thus, the benefits obtained from trade liberalisation are different among countries. A primary reason can be attributed to the comparative advantage facing developed and developing countries. Taglioni and Winkler (2016) argue that relocating the production activities across countries depend on several factors such as cost of labour and innovative capacity. This implies that developing countries are therefore more suitable to host labour intensive activities, while technology intensive production could be carried out in developed countries.

Baldwin and Lopez-Gonzalez (2015) show that structural factors, the geographical location, the size of the country, and industrial structure play an important role in GVC integration. In Figure 1, we show the mean value regarding the participation of GVC in the following sectors (rubber and plastic products, basic metal, food products and beverages, textile and wearing apparels, wood and paper products, chemical products, electrical equipment, manufacturing, and telecommunication). The graph shows that low technology intensive sectors (rubber and basic metal) have the lowest GVC participation rate while GVC participation in manufacturing and telecommunication sectors are among the highest. On average, GVC participation exhibits steady growth. However, we observe a declining trend in the case of the telecommunication sector.

Figure 2 shows the mean value of GVC participation at the macroeconomic level. The graph shows that UK, Netherland, and Spain display the highest level of GVC participation. Another important observation is that GVC growth has been steady over the last decade.

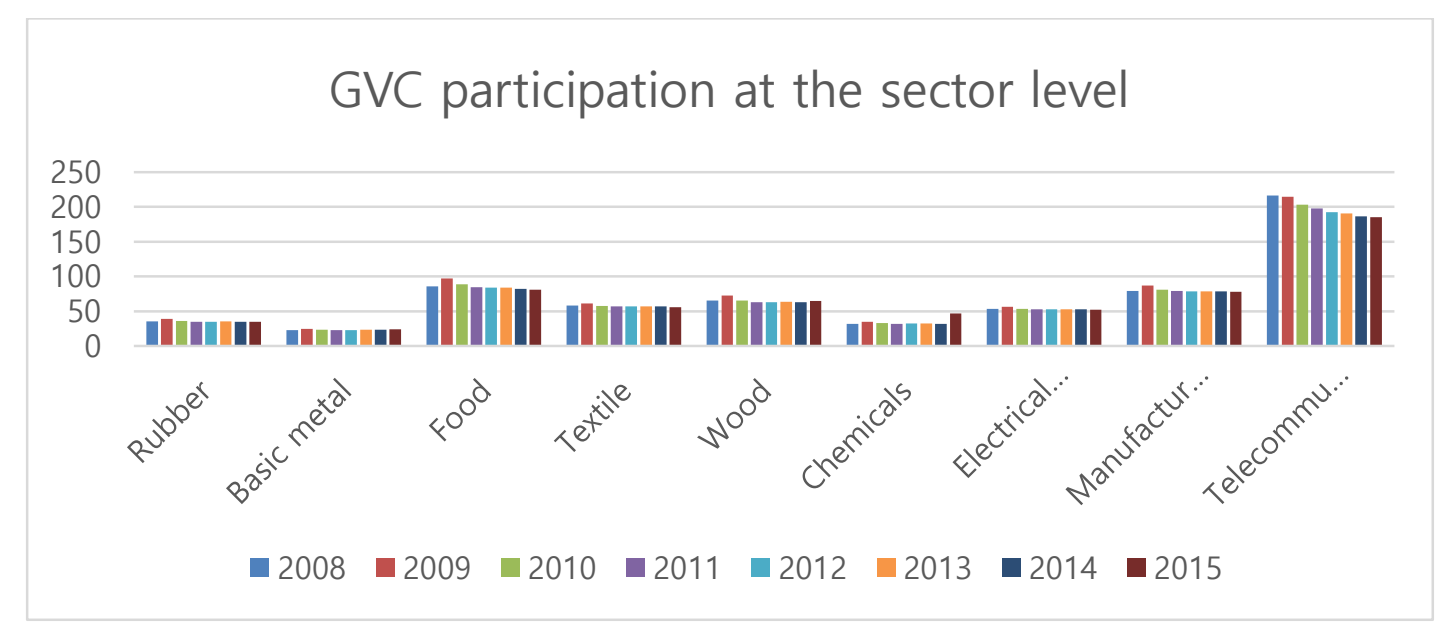

Figure 1. GVC participation at the sector level. Source: Author's calculation based on the EORA input-output database. GVC, global value chain.

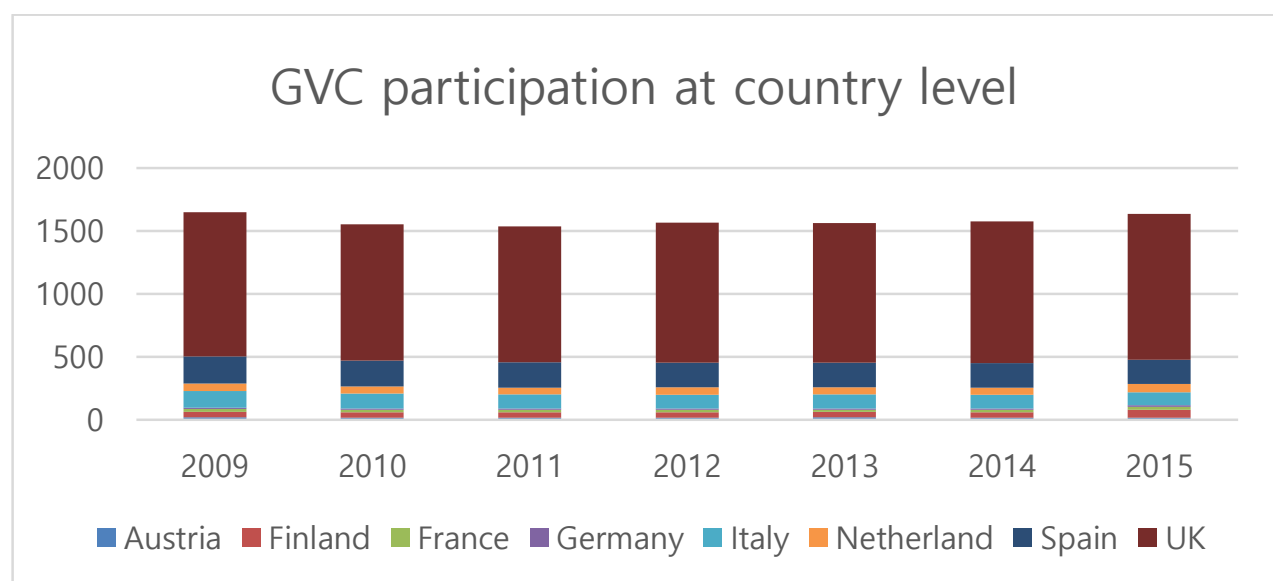

Figure 2. GVC participation at the country level. Source: Author's calculation based on the EORA input-output database. GVC, global value chain. 
The argument often mentioned to support GVC participation is that it enables firms to outsource production activities in which they are less efficient and focus on the activities where they have a comparative advantage. This specialization activities allow firms to invest their resources in innovation and capacity building to meet the international GVC standard which can in turn improve exports and production (Schwörer 2013). In this context, we attempt to estimate the impact of GVC in the case of European countries exports. The next section shows the data source and the model specification.

\section{Data source and model specification}

We use industry level data from OECD Structural Analysis Database (STAN). This database (https://www.oecd.org) provides detailed information regarding labour compensation, value added, capital stock, employment level and innovation. The multiregion input-output (MRIO) table gives information on domestic and foreign share of intermediate inputs required in the production of one unit of output. It is an input-output database (https://www.worldmrio.com) that provides the largest time series information for developed countries and developing countries that we are aware of. This data has been widely used in the literature (Amendolagine et al. 2019; Ndubuisi and Owusu 2020).

We compute our main variable (GVC) following the existing literature (Carril-Caccia and Pavlova 2020; Kummritz et al. 2017; Wang et al. 2019). This is because countries or firms that participate in GVC are referred to either as buyers (backward participant) or sellers (forward participant). Backward participation is measured as the share of foreign value that is included in a country's gross exports. Forward participation on the other hand is the share of domestic value that is included in the exports of a country.

Therefore, to capture a country's engagement in GVC, we use an indicator that includes backward and forward participation. GVC participation in a country $\mathrm{x}$, in sector $\mathrm{s}$, and time $\mathrm{t}$ is calculated as:

$$
G V C_{x, s, t}=F V A_{x, s, t}+D V A_{x, s, t} / G E_{x, s, t}
$$

Where $\mathrm{FVA}_{\mathrm{x}, \mathrm{s}, \mathrm{t}}$ stands for foreign value added embodied in a sector of a country's exports, $\mathrm{DVA}_{\mathrm{x}, \mathrm{s}, \mathrm{t}}$ stands for domestic value added that is recorded as inputs in the exports of a third country, and $\mathrm{GE}_{\mathrm{x}, \mathrm{s}, \mathrm{t}}$ is gross exports of country $\mathrm{x}$ in sector $\mathrm{s}$.

Since we are interested in understanding the comprehensive effects of GVC participation on exports, we estimate the independent effects of backward $\left(\mathrm{FVA}_{\mathrm{x}, \mathrm{s}, \mathrm{t}} / \mathrm{GE}_{\mathrm{x}, \mathrm{s}, \mathrm{t}}\right)$ and forward participation $\left(\mathrm{DVA}_{\mathrm{x}, \mathrm{s}, \mathrm{t}} / \mathrm{GE}_{\mathrm{x}, \mathrm{s}, \mathrm{t}}\right)$.

Our analysis focuses on 9 sectors and we rely on a Cobb-Douglas function to estimate the effects of GVC on exports. Our modelling specification consists of variables that can impact exports in a group of $\mathrm{N}$ countries $(\mathrm{i}=1, \ldots, \mathrm{N})$ and $\mathrm{J}$ industries $(\mathrm{j}$ $=1, \ldots, \mathrm{J})$. We estimate the following production function by assuming that in each industry $\mathrm{j}$ and country $\mathrm{i}$ at a time $\mathrm{t}$ takes the following form:

$$
Y_{i j t}=F_{j} A_{i j t}\left(K_{i j t}, L_{i j t}\right)
$$

where $\mathrm{L}$ represents Labor, A is technological efficiency, $\mathrm{K}$ is physical capital.

In the literature, bilateral export has been used to measure competitivity. It is the ratio of exports from country $\mathrm{m}$ to country $\mathrm{n}$ over exports from country a to country $\mathrm{b}$ in an industry $\mathrm{s}$. The subscript a indicates the parent country, $\mathrm{b}$ is the trading partner, and $\mathrm{s}$ denotes the industry.

$$
Y_{a b s} / y_{a b s}=f\left[\left(k_{a s} / k_{b s}\right),\left(a_{a s} / a_{b s}\right),\left(l_{a s} / l_{b s}\right)\right]+u_{t s}
$$

The explained variable (y) represents exports, (k) measures the capital stock to the number of employed in industry s, (a) is the innovation variable, (1) captures labour input. To assess the effects of GVC participation on exports, we follow the work of (Egger and Pfaffermayr 2005; Siedschlag and Zhang 2015) and include other important determinants of exports such as apparent consumption. Apparent consumption captures market size, it is calculated using: [gross production- (exports + imports) in a sector s. The innovation variable measures spending in R\&D. Labour input is calculated as labour compensation over value added. The definition of the variables and their sources are provided in the appendix section.

$$
\begin{aligned}
& \ln \left(y_{a b s} / y_{a b s}\right)=\beta_{0}+\beta_{1} \ln \left(k_{a s} / k_{b s}\right)+\beta_{2} \ln \left(a_{a s} / a_{b s}\right)+\beta_{3} \ln \left(l_{a s} / l_{b s}\right) \\
& +\beta_{4} \ln \left(a c_{a s} / a c_{b s}\right)+\beta_{5} \ln \left(g v c_{a s} / g v c_{b s}\right)+u_{t s}
\end{aligned}
$$


Even though we argue that GVC participation has the potential to boost exports, it is important to examine its effects in the context of European countries. Also, exports' growth is not spread evenly across countries because of several factors such as trade agreements and political issues.

Our full sample size comprises 9 industries over the period 2000-2015. The countries included in the study are: France, Germany, Spain, Netherland, Italy, Austria, UK and Finland. Thus, we have 1,080 observations in the sample. The period was chosen because of the availability of our main variable (GVC) participation.

\section{Research methodology}

In the literature, the pooled OLS has played an important role in examining the effects of relative factors of production on bilateral trade performances. In this study, we employ a log-linear regression of the pooled model as discussed in section 3. This model allows to solve many traditional problems related to time and cross- sectional analysis.

First, the model allows to overcome the problem of small sample bias because it considers country-year observations which provides robust predictors in the case of a multivariate framework analysis. A second advantage of this model is related to the variability of the data which is negligible. In practice, several national institutions appear to be temporarily invariant. This justifies the popularity of the model in the literature. A third advantage of this model concerns the ability to capture simultaneously time and space.

Given these benefits, several researchers have used pooled OLS to answer questions regarding the determinants of macroeconomic policies. Standard OLS regressions estimate tend to be inefficient because the errors are not independent across different periods. This suggests possible issues of serial correlation between country $i$ at time $t$ and country $i$ at time $t+1$. Finally, the data may present issues of heteroskedasticity. This is because there is a high variance across sub sets of nations. For instance, in our cases, the UK may have a higher and more volatile GVC participation compared to Italy. Therefore, the assumption of homoskedasticity in standard OLS may result in inappropriate estimates.

We also employ a two-stage quantile method as a sensitivity test because of the flexibility of the model. The model allows regressors to have different effects on the outcome variable. We use Stata 13 to run the analysis.

The next section presents the results. We start by showing the results at the macroeconomic level. Then, we present the results at the sectoral level.

\section{Empirical results}

This section is divided into two subsections: The first subsection discusses the effects of GVC participation at the macroeconomic or the country level. We also conduct a sensitivity test to strengthens our findings. The second subsection explores the effects of GVC participation at the industry level given the heterogeneity among sectors.

\subsection{GVC participation and bilateral exports: Aggregate level}

We start the analysis by presenting the results of the full sample. We consider the following of bilateral pairs (FranceGermany, Italy-Austria, Spain-Netherland, UK-Finland) which we refer as model $(1,2,3,4)$, respectively.

We follow Banga (2013) who suggests the separation of GVC participation into forward and backward participation as defined in section 3. This helps in providing a comprehensive understanding of how a country can benefit from GVC participation.

The results from Table 1 show that forward participation has no significant effects on exports in most of our model, only in the second column the relationship is negative and significant.

Another important finding is that the innovation variable has a significant and positive effect on exports, suggesting that high investment in R\&D can boost exports. Apparent consumption which is used to proxy market size is significant in all our estimations, suggesting that industries with large market size can support exports'growth.

The results from Table 2 indicate that backward participation has a negative and significant effect on exports. The coefficient is only positive and significant in the first column. While the results presented in the previous section suggest that on average GVC participation does not have a significant effect on exports, these results imply the opposite.

The control variable (innovation) is positive and significant in two columns, indicating that higher innovation activities cause an increase in exports. The estimated coefficients on labour cost in column (3) and (4) suggest that higher labour costs do not 
Table 1. Pooled OLS estimates (the dependent variable is exports)

\begin{tabular}{|c|c|c|c|c|}
\hline & (1) & (2) & (3) & (4) \\
\hline Log (forward participation) & $\begin{array}{c}-0.043 \\
(0.027)\end{array}$ & $\begin{array}{l}-0.591^{\text {**** }} \\
(0.110)\end{array}$ & $\begin{array}{c}-0.001 \\
(0.037)\end{array}$ & $\begin{array}{c}-0.057 \\
(0.034)\end{array}$ \\
\hline Log (innovation) & $\begin{array}{l}0.108^{\text {**** }} \\
(0.027)\end{array}$ & $\begin{array}{r}0.142 \\
(0.096)\end{array}$ & $\begin{array}{l}0.446^{* * *} \\
(0.098)\end{array}$ & $\begin{array}{l}0.990^{* * *} \\
(0.169)\end{array}$ \\
\hline Log (apparent consumption) & $\begin{array}{l}0.229^{* * * *} \\
(0.054)\end{array}$ & $\begin{array}{l}0.880^{* * *} \\
(0.127)\end{array}$ & $\begin{array}{l}-0.402^{* * *} \\
(0.126)\end{array}$ & $\begin{array}{l}3.461^{\text {**** }} \\
(0.329)\end{array}$ \\
\hline Log (capital stock) & $\begin{array}{l}0.619^{* * * *} \\
(0.145)\end{array}$ & $\begin{array}{c}-0.020 \\
(0.189)\end{array}$ & $\begin{array}{c}0.159^{*} \\
(0.095)\end{array}$ & $\begin{array}{l}-1.611^{\text {**** }} \\
(0.431)\end{array}$ \\
\hline Log (labour cost) & $\begin{array}{c}0.076 \\
(0.048)\end{array}$ & $\begin{array}{l}-0.775^{* *} \\
(0.330)\end{array}$ & $\begin{array}{c}0.414 \\
(0.333)\end{array}$ & $\begin{array}{l}4.582^{* * *} \\
(1.372)\end{array}$ \\
\hline Observations & 63 & 144 & 64 & 49 \\
\hline$r^{2}$ & 0.538 & 0.487 & 0.456 & 0.895 \\
\hline
\end{tabular}

Standard errors are in parentheses.

${ }^{*} p<0.1,{ }^{* *} p<0.05,{ }^{* * *} p<0.01$.

Table 2. Pooled OLS estimates (the dependent variable is exports)

\begin{tabular}{|c|c|c|c|c|}
\hline & (1) & (2) & (3) & (4) \\
\hline Log (backward participation) & $\begin{array}{l}0.353^{* * * *} \\
(0.027)\end{array}$ & $\begin{array}{l}-0.043^{* * *} \\
(0.020)\end{array}$ & $\begin{array}{l}-0.303^{\text {**** }} \\
(0.054)\end{array}$ & $\begin{array}{l}-0.031^{* *} \\
(0.013)\end{array}$ \\
\hline Log (innovation) & $\begin{array}{l}0.069^{\text {**** }} \\
(0.010)\end{array}$ & $\begin{array}{r}0.184 \\
(0.153)\end{array}$ & $\begin{array}{c}0.328^{*} \\
(0.127)\end{array}$ & $\begin{array}{l}-0.382^{* * *} \\
(0.113)\end{array}$ \\
\hline Log (apparent consumption) & $\begin{array}{l}0.138^{\text {**** }} \\
(0.023)\end{array}$ & $\begin{array}{c}0.951^{* * *} \\
(0.165)\end{array}$ & $\begin{array}{l}-0.586^{\text {**** }} \\
(0.178)\end{array}$ & $\begin{array}{l}1.504^{* * *} \\
(0.182)\end{array}$ \\
\hline Log (capital stock) & $\begin{array}{l}-0.040 \\
(0.082)\end{array}$ & $\begin{array}{c}-0.295 \\
(0.300)\end{array}$ & $\begin{array}{l}0.221^{\text {**** }} \\
(0.071)\end{array}$ & $\begin{array}{c}-0.035 \\
(0.186)\end{array}$ \\
\hline Log (labour cost) & $\begin{array}{l}0.282^{* * * *} \\
(0.025)\end{array}$ & $\begin{array}{c}-0.016 \\
(0.599)\end{array}$ & $\begin{array}{l}-0.620^{* *} \\
(0.271)\end{array}$ & $\begin{array}{c}-1.559^{* *} \\
(0.668)\end{array}$ \\
\hline Observations & 72 & 112 & 48 & 35 \\
\hline$r^{2}$ & 0.845 & 0.765 & 0.796 & 0.890 \\
\hline
\end{tabular}

Standard errors are in parentheses.

${ }^{*} p<0.1,{ }^{* *} p<0.05,{ }^{* * *} p<0.01$.

favour exports' growth. Capital stock on the other hand is only significant in the third column.

The results from Table 3 indicates that GVC participation are negatively associated with exports'growth. We only observe a statistically insignificant effect in the third column. The innovation coefficient has the expected sign. It is positive and significant as the literature has emphasized the benefits of innovation activities on exports (Crespi et al. 2014).

The analysis conducted at the macroeconomic level shows that on average GVC participation does not support exports' growth in the EU. Only in one instance, the relationship is positive and significant. These findings suggest that France and Germany can gain from GVC participation through foreign value added in the gross domestic exports. Next, we investigate the robustness of our baseline findings through an additional analysis.

We perform a two-stage quantile regression analysis to examine further the role of GVC participation. Because OLS or IV regression analysis assumes that the parameters are homogeneneous in the analysis, it may be necessary to investigate the effects of GVC participation assuming the patterns of the data are different.

Our sensitivity test (Table 4 and Table 6) supports the baseline results, in the sense that GVC participation is negatively associated with exports' growth. The coefficients on GVC participation are significant for every estimation. Another notable finding is that in most of our cases, innovation is positively associated with exports' growth. In Table 5, we only find a positive relationship between backward participation and exports in the first column. These findings suggest that the contribution of foreign value added has a positive effect on exports in France and Germany. This is in line with our baseline estimation results.

Next, we assess the effects of GVC participation on exports at the sectoral level. The literature has identified two main types of market structure. The fragmented industries which consist of firms that increase together with the growth of output. These 
Table 3. Pooled OLS estimates (the dependent variable is exports)

\begin{tabular}{|c|c|c|c|c|}
\hline & (1) & (2) & (3) & (4) \\
\hline Log (GVC participation) & $\begin{array}{l}-0.059^{* * *} \\
(0.025)\end{array}$ & $\begin{array}{l}-1.344^{* * *} \\
(0.136)\end{array}$ & $\begin{array}{c}-0.046 \\
(0.052)\end{array}$ & $\begin{array}{l}-0.082^{* *} \\
(0.040)\end{array}$ \\
\hline Log (innovation) & $\begin{array}{l}0.107^{\text {**** }} \\
(0.026)\end{array}$ & $\begin{array}{l}0.017 \\
(0.083)\end{array}$ & $\begin{array}{l}0.423^{\text {*** }} \\
(0.100)\end{array}$ & $\begin{array}{l}0.378 \\
(0.278)\end{array}$ \\
\hline Log (apparent consumption) & $\begin{array}{l}0.186^{\text {**** }} \\
(0.042)\end{array}$ & $\begin{array}{l}1.100^{* * *} \\
(0.112)\end{array}$ & $\begin{array}{l}-0.378^{\text {**** }} \\
(0.128)\end{array}$ & $\begin{array}{l}4.482^{* * *} \\
(0.482)\end{array}$ \\
\hline Log (capital stock) & $\begin{array}{l}0.547^{* * *} \\
(0.126)\end{array}$ & $\begin{array}{l}0.116 \\
(0.198)\end{array}$ & $\begin{array}{l}0.119 \\
(0.095)\end{array}$ & $\begin{array}{l}-1.509^{\text {**** }} \\
(0.451)\end{array}$ \\
\hline Log (labour cost) & $\begin{array}{l}0.086^{* *} \\
(0.043)\end{array}$ & $\begin{array}{l}-1.175^{\text {**** }} \\
(0.308)\end{array}$ & $\begin{array}{l}0.355 \\
(0.332)\end{array}$ & $\begin{array}{l}5.152^{* * *} \\
(1.274)\end{array}$ \\
\hline Observations & 72 & 128 & 64 & 42 \\
\hline$r^{2}$ & 0.514 & 0.673 & 0.464 & 0.430 \\
\hline
\end{tabular}

Standard errors are in parentheses.

${ }^{*} p<0.1,{ }^{* *} p<0.05,{ }^{* * * *} p<0.01$.

GVC, global value chain.

Table 4. Sensitivity test (forward participation): Two-stage quantile regressions

\begin{tabular}{|c|c|c|c|c|}
\hline & $(1)$ & (2) & (3) & (4) \\
\hline Forward participation & $\begin{array}{l}-0.057^{\text {**** }} \\
(0.015)\end{array}$ & $\begin{array}{l}-1.394^{* * *} \\
(0.058)\end{array}$ & $\begin{array}{l}-0.126^{* * *} \\
(0.029)\end{array}$ & $\begin{array}{l}-0.044^{\text {*** }} \\
(0.008)\end{array}$ \\
\hline Log (innovation) & $\begin{array}{l}0.110^{\text {*** }} \\
(0.008)\end{array}$ & $\begin{array}{l}0.064 \\
(0.80)\end{array}$ & $\begin{array}{l}0.137^{* *} \\
(0.059)\end{array}$ & $\begin{array}{l}1.249^{* * *} \\
(0.011)\end{array}$ \\
\hline Log (apparent consumption) & $\begin{array}{l}0.241^{\text {**** }} \\
(0.034)\end{array}$ & $\begin{array}{l}1.692^{* * *} \\
(0.076)\end{array}$ & $\begin{array}{l}-0.099^{* *} \\
(0.046)\end{array}$ & $\begin{array}{l}2.932^{* * * *} \\
(0.029)\end{array}$ \\
\hline Log (capital stock) & $\begin{array}{l}0.468^{* * * *} \\
(0.086)\end{array}$ & $\begin{array}{l}0.624^{* * * *} \\
(0.062)\end{array}$ & $\begin{array}{c}-0.013 \\
(0.046)\end{array}$ & $\begin{array}{l}-0.090^{\text {**** }} \\
(0.066)\end{array}$ \\
\hline Log (labour cost) & $\begin{array}{l}0.222^{* * *} \\
(0.045)\end{array}$ & $\begin{array}{l}-0.478^{\text {**** }} \\
(0.160)\end{array}$ & $\begin{array}{c}-0.142 \\
(0.226)\end{array}$ & $\begin{array}{l}2.668^{* * *} \\
(0.239)\end{array}$ \\
\hline Observations & 63 & 144 & 64 & 49 \\
\hline
\end{tabular}

Standard errors are in parentheses.

${ }^{*} p<0.1,{ }^{* *} p<0.05,{ }^{* * *} p<0.01$.

types of firms have low set-up costs and produce highly differentiated goods. In the segmented industries on the other hand, the number of firms remains the same even when the market size increases. This market is characterized by large set-up costs. Competition in this market focuses on the quality of the brand.

To estimate the impact of products that provides a large scope for product differentiation, we follow the work of (Scarpetta and Tressel 2002) who classifies industries based on product differentiation and concentration. A detailed description of the industries classification is provided in the appendix section (Table A1). We obtain two types of industries, low technology industries (basic metal, textile, rubber, wood), and high technology industries (chemical, electrical equipment, manufacturing, telecommunication).

In Table 7, we report the results of the interaction between GVC participation at the sectoral level. The findings lead to the conclusion that on average, GVC participation in low technology intensive industry is positively associated with exports' growth. The effect tends to be higher for low differentiated products.

GVC participation on the other hand is negatively associated with exports' growth in the case of high technology intensive industries. The effect in this case appears to be stronger for more differentiated products.

In our sample, the coefficient on GVC participation is only statistically insignificant for the manufacturing industry. This finding is consistent with the existing literature that GVC participation increase productivity through export upgrading (Harding and Javorcik 2012; Xu and Mao 2018).

Thus far, the analysis at the sectoral level supports the work of (Morris and Staritz 2017), that the effects of GVC participation varies across industries. They argue further that the adoption of GVC can actually lead to low level of economic upgrading. Taglioni and Winkler (2016) stress the complexity between GVC involvement and local sources. Using data from the food 
Table 5. Sensitivity test (backward participation): Two-stage quantile regressions

\begin{tabular}{|c|c|c|c|c|}
\hline & (1) & (2) & (3) & (4) \\
\hline Backward participation & $\begin{array}{l}0.396^{* * *} \\
(0.016)\end{array}$ & $\begin{array}{l}-0.029^{* * * *} \\
(0.010)\end{array}$ & $\begin{array}{l}-0.341^{\text {**** }} \\
(0.029)\end{array}$ & $\begin{array}{l}-0.048^{* * *} \\
(0.002)\end{array}$ \\
\hline Log (innovation) & $\begin{array}{l}0.048^{* * *} \\
(0.007)\end{array}$ & $\begin{array}{l}0.355^{\text {*** }} \\
(0.075)\end{array}$ & $\begin{array}{l}0.203^{* * *} \\
(0.054)\end{array}$ & $\begin{array}{l}-0.463^{* * *} \\
(0.012)\end{array}$ \\
\hline Log (apparent consumption) & $\begin{array}{l}0.192^{* * *} \\
(0.028)\end{array}$ & $\begin{array}{l}0.732^{* * *} \\
(0.070)\end{array}$ & $\begin{array}{l}-0.700^{\text {***** }} \\
(0.164)\end{array}$ & $\begin{array}{l}1.786^{* * * *} \\
(0.050)\end{array}$ \\
\hline Log (capital stock) & $\begin{array}{l}0.043^{* * *} \\
(0.048)\end{array}$ & $\begin{array}{l}-0.561^{\text {**** }} \\
(0.041)\end{array}$ & $\begin{array}{l}0.255^{\text {*** }} \\
(0.052)\end{array}$ & $\begin{array}{l}-0.219^{* * *} \\
(0.044)\end{array}$ \\
\hline Log (labour cost) & $\begin{array}{l}0.301^{* * *} \\
(0.025)\end{array}$ & $\begin{array}{l}0.775^{\text {**** }} \\
(0.279)\end{array}$ & $\begin{array}{l}-1.572^{\text {**** }} \\
(0.374)\end{array}$ & $\begin{array}{l}-2.571^{\text {**** }} \\
(0.137)\end{array}$ \\
\hline Observations & 72 & 112 & 48 & 35 \\
\hline
\end{tabular}

Standard errors are in parentheses.

${ }^{*} p<0.1,{ }^{* *} p<0.05,{ }^{* * *} p<0.01$.

Table 6. Sensitivity test (GVC participation): Two-stage quantile

\begin{tabular}{|c|c|c|c|c|}
\hline & (1) & (2) & (3) & (4) \\
\hline GVC participation & $\begin{array}{l}-0.123^{\text {***** }} \\
(0.011)\end{array}$ & $\begin{array}{l}-1.684^{\text {**** }} \\
(0.145)\end{array}$ & $\begin{array}{l}-0.052^{\text {**** }} \\
(0.017\end{array}$ & $\begin{array}{l}-0.150^{\text {*** }} \\
(0.010)\end{array}$ \\
\hline $\log$ (innovation) & $\begin{array}{l}0.090^{* * *} \\
(0.013)\end{array}$ & $\begin{array}{l}-0.102^{* *} \\
(0.058)\end{array}$ & $\begin{array}{l}0.298^{* * *} \\
(0.036)\end{array}$ & $\begin{array}{l}0.415^{\text {**** }} \\
(0.156)\end{array}$ \\
\hline Log (apparent consumption) & $\begin{array}{l}0.237^{\text {****}} \\
(0.011)\end{array}$ & $\begin{array}{l}1.257^{* * * *} \\
(0.069)\end{array}$ & $\begin{array}{l}-0.258^{* * *} \\
(0.037)\end{array}$ & $\begin{array}{l}4.617^{* * * *} \\
(0.279)\end{array}$ \\
\hline Log (capital stock) & $\begin{array}{l}0.688^{* * *} \\
(0.054)\end{array}$ & $\begin{array}{l}0.431^{* * *} \\
(0.090)\end{array}$ & $\begin{array}{l}-0.040 \\
(0.042)\end{array}$ & $\begin{array}{l}-1.854^{* * *} \\
(0.207)\end{array}$ \\
\hline Log (labour cost) & $\begin{array}{l}0.077^{\text {*** }} \\
(0.013)\end{array}$ & $\begin{array}{l}-1.781^{\text {**** }} \\
(0.153)\end{array}$ & $\begin{array}{l}0.363 \\
(0.170)\end{array}$ & $\begin{array}{l}4.948^{* * * *} \\
(0.312)\end{array}$ \\
\hline Observations & 72 & 128 & 64 & 42 \\
\hline
\end{tabular}

Standard errors are in parentheses.

${ }^{*} p<0.1,{ }^{* *} p<0.05,{ }^{* * * *} p<0.01$.

GVC, global value chain.

sector, they show that the linkages to local suppliers are above $76 \%$ in Vietnam and less than $50 \%$ in Mozambique.

Our analysis also shows that GVC participation for the electrical equipment industry has the strongest effect on exports' growth. Crino and Ogliari (2017) have documented that differentiated products have greater room for export adjustment. This is because producers in this industry require more sophisticated inputs and knowledge into the value chains. Despite the high participation of value chains across industries, one of the possible explanation for the negative effect of GVC participation and exports is that countries end up supplying products that have less scope to enhance the value of exports. The negative and significant coefficients on GVC is also a signal for EU countries to look for other market to reap the full benefit of GVC integration. The findings of this study also complement the debate in the literature that although GVC participation may extend a country's scope for exports, the effects are different across countries and industries.

\section{Discussion and implications}

We begin by discussing the results from the aggregate sample. The results from table 1 have two main implications. Firstly, it suggests that the contribution of domestic value (forward participation) does not support exports'growth. Secondly, column 2 shows that domestic value actually reduces exports'growth. Policy makers need to take into consideration the strengths of domestic linkages in the implementation of GVCs policies. Further, the results show that the structure of an economy and domestic linkages are important elements in the analysis of GVCs.

In Table 2, we consider the effects of backward participation and show that it has a negative and significant effect on exports. It strengthens the idea to disentangle GVC participation into forward and backward participation. Although different industries are considered in our analysis, we find a positive effect between GVC participation and exports'growth in the first column. 
Table 7. GVC and industry classification

\begin{tabular}{lcccccccc}
\hline & $\begin{array}{c}\text { Log } \\
\text { (basic metal) }\end{array}$ & $\begin{array}{c}\text { Log } \\
\text { (textile) }\end{array}$ & $\begin{array}{c}\text { Log } \\
\text { (wood) }\end{array}$ & $\begin{array}{c}\text { Log } \\
\text { (chemicals) }\end{array}$ & $\begin{array}{c}\text { Log } \\
\text { (electrical } \\
\text { equipment) }\end{array}$ & $\begin{array}{c}\text { Log } \\
\text { (manu- } \\
\text { facturing) }\end{array}$ & $\begin{array}{c}\text { Log } \\
\text { (telecomuni- } \\
\text { cation) }\end{array}$ & $\begin{array}{c}\text { Log } \\
\text { (rubber) }\end{array}$ \\
Log (GVC) & $0.104^{* * *}$ & $1.423^{* * *}$ & $-0.908^{* * *}$ & $-0.093^{*}$ & $-1.867^{* * *}$ & -0.155 & $-0.982^{* *}$ & $0.545^{* * *}$ \\
& $(0.025)$ & $(0.433)$ & $(0.056)$ & $(0.047)$ & $(0.401)$ & $(0.206)$ & $(0.253)$ & $(0.096)$ \\
Log & 0.027 & $0.352^{*}$ & $0.508^{* * *}$ & -0.174 & $-0.274^{*}$ & -0.300 & -0.010 & $-0.233^{* * *}$ \\
(innovation) & $(0.199)$ & $(0.122)$ & $(0.126)$ & $(0.147)$ & $(0.143)$ & $(0.370)$ & $(0.368)$ & $(0.079)$ \\
Log (apparent & -0.064 & -0.135 & $-0.648^{*}$ & 0.129 & $0.588^{* * *}$ & $0.729^{* *}$ & $1.102^{*}$ & $0.503^{* * *}$ \\
consumption) & $(0.080)$ & $(0.130)$ & $(0.223)$ & $(0.122)$ & $(0.067)$ & $(0.340)$ & $(0.426)$ & $(0.115)$ \\
Log (capital & -0.174 & $0.648^{* * *}$ & -0.010 & $0.129^{*}$ & $0.632^{* * *}$ & $0.442^{*}$ & -0.675 & $-0.727^{* * *}$ \\
stock) & $(0.192)$ & $(0.172)$ & $(0.206)$ & $(0.047)$ & $(0.096)$ & $(0.254)$ & $(0.921)$ & $(0.204)$ \\
Log (labour & $1.905^{* *}$ & $-1.338^{* * *}$ & 0.574 & $-0.529^{* *}$ & $-1.007^{* * *}$ & $-1.032^{*}$ & -0.675 & 0.136 \\
cost) & $(0.021)$ & $(0.391)$ & $(0.639)$ & $(0.219)$ & $(0.313)$ & $(0.524)$ & $(0.921)$ & $(0.399)$ \\
$r^{2}$ & 0.820 & 0.985 & 0.993 & 0.714 & 0.918 & 0.925 & 0.955 & 0.918 \\
\hline Stant & & & & & &
\end{tabular}

Standard errors are in parentheses.

${ }^{*} p<0.1,{ }^{* * *} p<0.05,{ }^{* * * *} p<0.01$.

GVC, global value chain

This indicates that backward participation in the value chains can boost exports'growth. The results presented in Table 3 indicates that GVC participation are negatively associated with exports'growth.

Our results corroborate the findings of Taglioni and Winkler (2016) that not all countries have benefitted from participating in GVCs. Our baseline results from a macroeconomic perspective indicate three main findings: (i) GVC participation has a negative and significant effect on bilateral exports in most of our specifications; (ii) backward participation is negatively associated with bilateral exports in most of our cases except for France and Germany where the relationship becomes positive - One possible explanation is that the high share of foreign value added improved the quality of products in the latter case; (iii) forward participation does have a significant effect on bilateral exports. These findings are consistent after using another instrument.

Our control variable (innovation) is positive and significant in most of our cases, suggesting that R\&D help introduce new products in the market which in turn increase demand. This shows that innovation is an important factor for trade performance. Apparent consumption is also positive and significant. This supports the idea that market size can support trade performance.

Regarding the sectoral analysis, the estimated coefficients show that on average, GVC participation in low technology intensive industry contributes positively to exports' growth. For instance, a $1 \%$ increase in the GVC participation causes a $1.42 \%$ and $0.54 \%$ rise in the exports'growth in the textile and the rubber industries, respectively.

However, GVC participation in the high technology intensive industries is negatively associated with exports' growth. A 1\% increase in GVC leads to a $1.86 \%$ and $0.98 \%$ fall in exports in the Electrical and telecommunication industries.

These results imply that GVC participation does not automatically increase exports. The study suggests that companies should focus on increasing value chain participation in the low technology intensive industries, especially in the textile industries given its high growth potential. The sectoral analysis also shows that countries can benefit from GVC participation by specialising on products that stimulate a new demand. The structure of an economy such as infrastructure and investment in research can help strengthens GVC participation.

\section{Conclusion}

Economic growth and sustainable development require innovation and technological upgrading. This implies a welldiversified economy to meet the growing and changing demand of the market. The participation of GVC provides an avenue for countries to increase exports. This can be achieved through the imports of technologies and higher value intermediates inputs. We examine the effects of GVC participation on exports across countries and sectors using a complete coverage of indicators that measure a country's involvement in GVC.

The results at the macroeconomic level indicate that higher participation in value chains is negatively associated with exports' growth. Specifically, GVC participation and forward participation have a negative effect on exports. However, backward participation is positive and significant in the case of bilateral trade between France and Germany. The results at the sectoral level highlight the different effects of GVC across industries. In the sample, industries that are classified as high technology 
intensive show that there is a negative relationship between GVC and exports. In the low technology intensive industries, there is a positive link between GVC participation and exports.

These findings have important implications for policy, especially with the stagnant economic growth countries in Europe are facing. It shows that GVC participation of developed countries alone is not sufficient to drive economic growth in the region. A possible reason could be the similar level of development and economic structure. Hence, the EU countries would gain by ensuring that other regions participate in the value chains process. Policies that lift trade barriers in the low technology intensive sectors should be encouraged.

We acknowledge some limitations in this study that could be examined in the future. First, the study can be conducted in the context of developing economies. Also the effect of GVC participation can be assessed in the context of South-North or NorthSouth trade. Lastly, discussions on which market segment benefit from the GVC in the context of developing economies can be explored. This would help complement this study by assessing the role of GVC in countries that have a low level of economic development.

\section{Acknowledgement}

This work is based on the research supported by the National Research Foundation of South Africa (Grant Number: 118873)

\section{References}

Amendolagine, V., Presbitero, A. F., Rabellotti, R., Sanfilippo, M., 2019. Local sourcing in developing countries: The role of foreign direct investments and global value chains. World Development 113, 73-88.

Baldwin, R., 2014. Trade and industrialization after globalization's second unbundling: How building and joining a supply chain are different and why it matters, In: Feenstra, R. C., Taylor, A. M. (Eds), Globalization in an Age of Crisis: Multilateral Economic Cooperation in the Twenty-first Century. University of Chicago Press, Chicago, IL.

Baldwin, R., Lopez-Gonzalez, J., 2015. Supply-chain trade: A portrait of global patterns and several testable hypotheses. The World Economy 38, 1682-1721.

Banga, R., 2013. Measuring value in global value chains. UNCTAD Regional Value Chains Background Paper \#RVC-8.

Barrientos, S., Visser, M., 2012. South African horticulture: Opportunities and challenges for economic and social upgrading in value chains. Capturing the Gains Working Paper 2012/12.

Bernard, A. B., Jensen, J. B., 2004. Exporting and productivity in the USA. Oxford Review of Economic Policy 20, 343-357.

Carril-Caccia, F., Pavlova, E., 2020. Mergers and acquisitions \& trade: A global value chain analysis. The World Economy 43, 586-614.

Collier, P., Venables, A. J., 2007. Rethinking trade preferences: How Africa can diversify its exports. The World Economy 30, 1326-1345.

Constantinescu, C., Mattoo, A., Ruta, M., 2019. Does vertical specialisation increase productivity? The World Economy 42, 2385-2402.

Crespi, G., Tacsir, E., Vargas, F., 2014. Innovation and productivity in services: Empirical evidence from Latin America. UNUMERIT Working Paper 2014-068.

Crino, R., Ogliari, L., 2017. Financial imperfection, product quality, and international trade. Journal of International Economics. 104, 63-84.

Egger, P., Pfaffermayr, M., 2005. The determinants of intrafirm trade: In search for export-import magnification effects. Review of World Economics 141, 648-669.

Harding, T., Javorcik, B. S., 2012. Foreign direct investment and export upgrading. The Review of Economics and Statistics 94, 964-980.

Kummritz, V., Taglioni, D., Winkler, D., 2017. Economic upgrading through global value chain participation: Which policies increase the value added gains? World Bank Policy Research Working Paper 8007.

Lee, J., Gereffi, G., Barrientos, S., 2011. Global value chains, upgrading and poverty reduction. Capturing the Gains Briefing Note No. 3. Available at: http://www.capturingthegains.org/pdf/ctg_briefing_note_3.pdf

Lopez-Gonzalez, J., 2016. Using foreign factors to enhance domestic export performance: A focus on Southeast Asia. OECD Trade Policy Papers, No. 191.

Morris, M., Staritz, C., 2017. Industrial upgrading and development in Lesotho's apparel industry: Global value chains, foreign 
direct investment, and market diversification. Oxford Development Studies 45, 303-320.

Ndubuisi, G., Owusu, S., 2020. How important is GVC participation to export upgrading. MERIT Working Papers 2020-026. OECD, 2013. Interconnected Economies: Benefiting from Global Value Chains. OECD, Paris, France.

Pahl, S., Timmer, M. P., 2019. Do global value chains enhance economic upgrading? A long view. The Journal of Development Studies 56, 1683-1705.

Rodrik, D., 2013. Unconditional convergence in manufacturing. The Quarterly Journal of Economics 128, 165-204.

Rodrik, D., 2018. New technologies, global value chains, and developing economies. National Bureau of Economic Research, Working Paper No. 25164.

Scarpetta, S., Tressel, T., 2002. Productivity and convergence in a panel of OECD industries: Do regulations and institutions matter? OECD 23 Working Paper No. 342.

Schwörer, T., 2013. Offshoring, domestic outsourcing and productivity: Evidence for a number of European countries. Review of World Economics 149, 131-149.

Siedschlag, I., Zhang, X., 2015. Internationalisation of firms and their innovation and productivity. Economics of Innovation and New Technology 24, 183-203.

Taglioni, D., Winkler, D., 2016. Making Global Value Chains Work for Development. The World Bank, Washington, DC.

Timmer, M., Erumban, A. A., Los, B., Stehrer, R., de Vries, G. J., 2014. Slicing up global value chains. The Journal of Economic Perspectives 28, 99-118.

Wang, J., Wan, G., Wang, C., 2019. Participation in GVCs and $\mathrm{CO}_{2}$ emissions. Energy Economics 84, 104561.

World Trade Organization [WTO] \& Institute of Developing Economies- Japan External Trade Organization [IDE-JETRO], 2011. Trade patterns and global value chains in East Asia: From trade in goods to trade in tasks. Available at: https://www.wto.org/english/res_e/booksp_e/stat_tradepat_globvalchains_e.pdf

Xu, J., Mao, Q., 2018. On the relationship between intermediate input imports and export quality in China. Economics of Transition and Institutional Change 26, 429-467. 


\section{Appendix}

Table A1. Characteristics of industries in the sample

\begin{tabular}{lcc}
\hline \multicolumn{1}{c}{ Industry name } & Product differentiation & Market structure \\
Food products and beverages & D & LT \\
Basic metal and fabricated metal & D & LT \\
Textile, wearing apparel, leather and related products & H & LT \\
Wood, paper product and printing & H & LT \\
Rubber and plastic products & H & LT \\
Other manufacturing & H & HT \\
Communication equipment & D & HT \\
Chemical and chemical products & D & HT \\
Electrical equipment & D & HT
\end{tabular}

HT and LT stand respectively for high-technology and low-technology industries. D and H stand for differentiated products and homogeneous or low differentiated products.

Table A2. List of variables, definition and sources

\begin{tabular}{|c|c|c|}
\hline Variable & Definition & Source \\
\hline Forward participation & Domestic value that is included in a country's gross exports. & Author's calculation based on EORA MRIO \\
\hline Backward participation & Foreign value that is included in a country's gross exports. & Author's calculation based on EORA MRIO \\
\hline GVC participation & Foreign value and domestic value over gross exports & Author's calculation based on EORA MRIO \\
\hline Innovation & Research and development expenditure & STAN database \\
\hline Apparent consumption & $\begin{array}{l}\text { It is calculated using: [gross production minus (exports + } \\
\text { imports) in a sector }\end{array}$ & $\begin{array}{l}\text { Author's calculation based on STAN } \\
\text { database }\end{array}$ \\
\hline Capital cost & Capital stock to the number of employed in industry & $\begin{array}{l}\text { Author's calculation based on STAN } \\
\text { database }\end{array}$ \\
\hline Labour cost & Labour compensation over value added. & $\begin{array}{l}\text { Author's calculation based on STAN } \\
\text { database }\end{array}$ \\
\hline
\end{tabular}

MRIO, multi-region input-output; GVC, global value chain; STAN, structural analysis database. 